Marquette University

e-Publications@Marquette

College of Communication Faculty Research and

Publications

Communication, College of

$5-1-2013$

\title{
The Ethics of Conscious Capitalism: Wicked Problems in Leading Change and Changing Leaders
}

Jeremy P. Fyke

Marquette University, jeremy.fyke@marquette.edu

Patrice M. Buzzanell

Purdue University

Accepted version. Human Relations, Vol. 66, No. 12 (December 2013). DOI. (C) 2013 SAGE

Publications. Used with permission. 


\title{
The Ethics of Conscious Capitalism: Wicked Problems in Leading Change and Changing Leaders
}

\author{
Jeremy P. Fyke \\ Diederich College of Communication, Marquette University \\ Milwaukee, WI \\ Patrice M. Buzzanell \\ Brian Lamb School of Communication, Purdue University \\ W. Lafayette, IN
}

\begin{abstract}
Given corporate scandals, organizational crises, and accounting irregularities (e.g., Citigroup, BP oil spill, Enron, Arthur Andersen), leadership ethics has grown in relevance. The current study takes a discursive approach to engage in a multimethod case study of a consulting and leadership development firm that takes Conscious Capitalism as the impetus for and target of leader development. Using constructivist grounded theory and critical discourse analysis, we reveal themes and "best practices" voiced by consultants and clients for developing ethical leaders, as well as micro- and macro-level tensions and challenges: structuring-releasing; expandingcontracting; opening up-closing; and collaborating-competing. Our critical approach contributes (a) a critique of Conscious Capitalism as a Discourse that appears to offer hope for business and societal transformation and (b) a critique of ethical leadership development through embedded power relations and the complex discursive processes within and driven by leadership development at the intersection of various d/Discourses. This research helps explain some of the challenges involved in developing ethical leaders. We reveal that although Conscious Capitalism appears to offer solutions to many of today's social problems, developing ethical leaders ironically leads to problems that are 'wicked.'
\end{abstract} permission has been granted for this version to appear in e-Publications@Marquette. [Publisher] does not grant permission for this article to be further copied/distributed or hosted elsewhere without the express permission from [Publisher].] 
NOT THE PUBLISHED VERSION; this is the author's final, peer-reviewed manuscript. The published version may be accessed by following the link in the citation at the bottom of the page.

Keywords: Ethics, Leader(ship) Development, Conscious Capitalism, d/Discourse, Critical Discourse Analysis, Organizational Justice, Wicked Problems, Mindfulness

\section{Introduction}

In today's increasingly global business environment, organizations are renewing their efforts to raise their standards of ethical business conduct (McCann and Holt, 2009). Given corporate scandals, organizational crises, and accounting irregularities (e.g., Enron, Citigroup, Arthur Andersen, BP oil spill), leadership ethics and organizational justice have grown in relevance. In a world where businesses and stakeholders connect instantaneously through technologies (e.g., Twitter, Facebook, YouTube), public outrage over ethics and justice can have deleterious effects over a company's goodwill and competitiveness (e.g., Nike's labor practices, see Bies and Greenberg, 2002; Folger and Skarlicki, 2008). Questionable ethical decisions have led academics and practitioners to wonder 'what's wrong with our leaders' (Brown and Treviño, 2006: 595). As the research focus shifts away from victims' perceptions and toward the decision makers themselves, behavioral ethics is increasing in importance. This shift has heightened interest from diverse fields including organizational behavior, business ethics, and industrial/ organizational psychology (Rupp and Bell, 2010). Despite recent work exploring ethical leadership (e.g., Akrivou et al., 2011; Brown and Mitchell, 2010; Kenny, 2010; Mihelič et al., 2010; Toor and Ofori, 2009), research on ethical leader development is surprisingly lacking.

The current study takes a discursive approach-examining talk and text in everyday social contexts as well as paradigm-shifting macrodiscourses in which texts and collections of texts are embedded and shaped (Fairhurst, 2007; Larsson and Lundholm, 2010; Phillips and Oswick, 2012)-to engage in a multimethod case study of a consulting and leadership development firm. The company fosters positive social change by developing ethical leaders and organizations, a process that they call 'The Work.' Using a discursive lens, this research is attuned to micro- and macro-level discourses (d/Discourse) and contexts that constitute and are constituted by organizational life (Alvesson and Kärreman, 2000). Our aim in this essay is not to assess

[Citation: Journal/Monograph Title, Vol. XX, No. X (yyyy): pg. XX-XX. DOI. This article is (C [Publisher's Name] and permission has been granted for this version to appear in e-Publications@Marquette. [Publisher] does not grant permission for this article to be further copied/distributed or hosted elsewhere without the express permission from [Publisher].] 
the impact of the consultant's advice and training on the clients; rather, we are interested in how consultants and clients negotiate meaning over various ideologies at the intersection of $d$ /Discourses. Despite the need for ethical leadership, research has not fully linked context and practices (e.g., training, role-modeling, ethical codes). As Akrivou et al. (2011) note, contextual pressures in today's business play key roles in handicapping leaders' abilities to act ethically. Even with best intentions and clear moral principles and personal obligations, as in deontic justice (Cropanzano et al., 2003; Folger et al., 2005; Folger and Salvador, 2008), other concerns (e.g., social, economic) influence behavior (Cropanzano and Stein, 2009). In line with a discursive approach, our account is, by necessity, descriptive and critical for, as Fairhurst (2009) argues, leadership should be explored in situ, while uncovering whose interests are served in struggles for dominance.

We take Conscious Capitalism (CC) as foundation for and target of leader development. As such, we explore the complex discursive processes embedded within and driven by leadership development. To CC proponents, ethical business issues are best solved through increased consciousness beginning with leaders and amplifying throughout the system. Research indicates that self-reflexive and morally responsive leaders are ethical (Brown and Treviño, 2006), with reflection aiding self-awareness and ethical behavior (Akrivou et al., 2011). Consciousness and self-reflexivity may be key unlocking moves for increases in moral rule-following decision rubrics by business leaders. However, it remains unclear whether and how moral rulefollowing guidelines and internalized codes of ethics can be developed, and with what consequences.

Despite acclaim from practitioners and popular outlets (e.g., Aburdene, 2005; Strong, 2009), CC has received little scholarly attention. We report on a field study of a consulting and leadership development firm committed to CC. Much leadership work takes a prescriptive stance, arguing for and against certain norms and techniques (Cunliffe, 2009). This project, by contrast, takes a critical perspective that enables researchers to be open to the partial and fragmented discursive struggles characterizing organizational life (Alvesson and Deetz, 2000). Our critical perspective on organizational 
$d$ /Discourse is sensitive and open to the power dynamics that characterize organization change and development, an approach normally favoring trends toward positive approaches (Cameron, Dutton, \& Quinn, 2003; Marshak \& Grant, 2008). We document and critique what happens when one firm attempts to develop ethical leaders. Our analysis gets at a question posed by recent research--'can ethical leadership be identified and developed?' (Brown and Treviño, 2006: 608)--to which we add 'and with what consequences?'

Our contributions in this essay are threefold. First, we provide a critique of CC as an emerging business Discourse that appears to offer hope for business and societal transformation. Since ' $D$ 'iscourses tend to be paradigm-shifting (Phillips and Oswick, 2012), and thus highly influential, scholarship must avoid blind acceptance and grapple with the implications of these ideologies. Second, our attention to organizational tensions affords a basis for critique of ethical leadership development based on embedded power relations at micro- and macro-levels (see Gordon et al., 2009). In this respect, our engagement with 'small $\mathrm{d}$ ' and 'big $\mathrm{D}$ ' avoids the dichotomization of discourse levels present in many discourse studies (Alvesson and Kärreman, 2011a, 2011b; Phillips and Oswick, 2012). Finally, business is increasingly seen as a lever for change in the world; a vehicle for tackling overly complex or 'wicked' problems (Rittel and Webber, 1973; Waddock and McIntosh, 2011) such as poverty and environmental sustainability. CC has emerged as one avenue for helping business grapple with wicked problems (Waddock and McIntosh, 2011). However, we find that dealing with ethical dilemmas by training leaders to be more ethical through $\mathrm{CC}$ can, itself, become 'wicked.' 
NOT THE PUBLISHED VERSION; this is the author's final, peer-reviewed manuscript. The published version may be accessed by following the link in the citation at the bottom of the page.

\section{Review of Literature}

\section{Ethics and Organizational Justice}

Because of the sheer persuasive potential of leadership (see Fairhurst, 2011), leadership is imbued with ethics and critical for an organization's overall culture (Brown and Mitchell, 2010; Treviño et al., 2003). Issues of leadership ethics are not new, but a resurgent interest has led to development of ethical leadership constructs. Brown et al. (2005) define ethical leadership as 'the demonstration of normatively appropriate conduct through personal actions and interpersonal relationships, and the promotion of such conduct to followers through two-way communication, reinforcement, and decision-making' (p. 120). In leadership processes, leader behavior is powerful, as followers tend to emulate what they see in role models. Indeed, unethical and unjust behavior tends to have a trickle-down effect, such that when institutions are perceived as unfair and/or unethical, individuals become less likely to behave ethically (Cropanzano and Stein, 2009). On the other hand, Mihelič et al. (2010) note that the more leaders translate values and moral convictions to behavior (i.e., 'walk their talk'), the more followers trust and respect leaders and follow their lead. Yet, demonstration and reinforcement of normative conduct is necessary but not sufficient. Given the complexities in a constantly changing global world (McCann and Holt, 2009), increased corporate scandals, and cases of failed leadership, ethical questions center on crucial social problems (Kuhn and Ashcraft, 2003).

Other research explores ethical codes of conduct and normative standards for ethical behavior. However, as Seeger and Kuhn (2011) note, having principled moral obligations, ethical codes, or normative standards in place by no means guarantees compliance. Indeed, Enron executives' misdeeds occurred despite extensive ethical codes (Seeger and Ulmer, 2003). The Enron case highlights embedded structural incommensurabilities between pushes for efficiency and return on investment as well as needs for transparency and ethical standards. It presents an intractable conflict with which Enron leaders struggled mightily, that is, a 'wicked problem' (Rittel and Webber, 1973)-that is ill-formulated and has unclear answers and solutions not easily 
identifiable in the short-term (Camillus, 2008). A similar intractable conflict between justice and institutional reputation surfaced in the sexual abuse scandal at Penn State University.

For leaders, deontic justice research explains decision making in terms of moral rule-following and internalized standards of justice and ethics (e.g., Cropanzano et al., 2003; Cropanzano and Stein, 2009; Rupp and Bell, 2010). Another way to consider deontic justice perspectives is through the concept of mindfulness. Being mindful requires constant awareness and (re)appraisal of internalized moral standards (i.e., deontic justice). Theories in the area of moral standards remain in the nascent stage and are in need of theory development (see Cropanzano and Stein, 2009). Mindfulness provides such a means for development by requiring that individuals look at beliefs, values, and worldviews to better engage with others. Although not examining mindfulness specifically, Akrivou et al. (2011) explored the role of solitude in ethical decision making, which they defined as 'a voluntary activated state for the purpose of enhancing the quality of individual reflection and mental experience which has an inner- and/or an outer-directed focus' (122). In their conceptualization is the importance of reflection, a close relative of mindfulness. They argue that solitude positively affects authentic ethical leadership behaviors and in turn perceived fairness and integrity. Thus, it would appear that reflection and mindfulness serve an all-important albeit underexplored function for leaders. Despite Akrivou et al.'s discussion of contextual factors that mitigate time for reflection (e.g., speed, competition, communication demands), less is known about how these factors affect leadership development efforts. Indeed, executives rarely intentionally behave unethically (Akrivou et al., 2011).

We are left then with a slippery process by which ethical conduct can be learned and put into practice. Given the speed with which leaders are asked to make decisions, combined with contextual pressures of competition and a global marketplace, we wonder whether leaders have the resources to carve out the 'mental space to disconnect and reflect on how to combine effectiveness and ethical role modeling' (Akrivou et al., 2011:121) or a space to be mindful and consider unintended consequences, even with best efforts to develop or teach ethical leaders. Despite a stated focus on leadership 
development (e.g., Avolio and Gardner, 2005), little research actually engages in empirical investigation of organizations that operate in that space. Rather, extant research remains largely normative and anecdotal (Brown and Treviño, 2006; Rubin et al., 2010), focusing on how leaders can avoid missteps (Brown, 2007; Mihelič et al., 2010) and how ethical leadership can be facilitated throughout organizational cultures (Schweitzer et al., 2004).

\section{Conscious Capitalism}

Conscious Capitalism (CC), popularized by John Mackey, founder of Whole Foods, promises companies a way to rethink their purposes in the world, and offers companies a different, integrated entrée into corporate social responsibility (CSR) and related initiatives. CC, therefore, is one of several 'general and prevalent systems for the formation and articulation of ideas in a particular period of time' (Alvesson \& Kärreman, 2000: 1126). Recently, the world has heard voices calling loudly for a reappraisal of capitalism and the way business is done. Consider the Occupy Wall Street movement that spread to over 1000 cities worldwide. The Occupy movement signals disgust over corporate greed and a call for a more humane form of capitalism where social values are at the center of business (Sivakumar, 2011).

CC's impetus is that the way business is done is not sustainable. Rather than eschewing capitalism, 'leaders [must] re-think why their organizations exist and acknowledge their companies' roles in the interdependent global marketplace' ('Conscious Capitalism', 2012: para 3). Recognizing marketplace interdependence requires a high level of mindfulness on the part of leaders ('Conscious Capitalism', 2012), and deep systemic change to organizational cultures (Visser, 2011). CC has four tenets: spiritually-evolved, self-effacing servant leaders; a conscious culture; a stakeholder orientation; and a higher purpose, one that transcends profit maximization. As noted earlier, organizational culture is critical for a just and ethical operation. From a CC (2012) perspective, a conscious culture is one that is captured by the acronym TACTILE (trust, authenticity, caring, transparency, integrity, learning, empowerment). Looking at this acronym, it can be theorized that a conscious culture is one where justice, in all its forms 
(i.e., distributive, procedural, interactional, see Cropanzano and Stein, 2009), is a top priority for leaders. Conscious leaders are those who are mindful of their behaviors and ethical convictions (as in deontic justice, see Cropanzano et al., 2003; Rupp and Bell, 2010), as they work toward the betterment of their organizations and society.

As such, CC is inherently concerned with business ethics. The principle of voluntary exchange (e.g., between businesses and customers), upon which capitalism is based, provides the ethical foundation of businesses (Mackey, 2009). Businesses are expected to behave ethically in this voluntary exchange, and CC assumes that everything in business can be done either consciously or unconsciously. The vehicle through which consciousness in business is achieved is through purpose, the reason for a company to exist beyond its profit-making objective (FLOW Overview, n.d.). A company's purpose must be created to achieve higher levels of consciousness about ways that it contributes to the greater good. However, getting companies to be conscious of these ways requires reflection and reflexivity on the part of leadership. The requisite time and energy needed to carve out the 'mental space' (Akrivou et al., 2011) for reflexivity in today's hypercompetitive business milieu stands in tension with pressing concerns for action faced by organizational decision makers.

\section{Organizational Tensions and Complexities}

In a world where rationality and order permeates business theory and practice (Trethewey and Ashcraft, 2004), organizational communication scholars provide insight into members' messy and conflicting experiences as they live with individual and organizational transformation tensions (Jian, 2007; Mumby, 2005; Putnam et al., 2005; Seo et al., 2004; Tracy, 2004). For leaders, the tumultuous work environment, marked by a weak economy and increased competition, means that organizational members are pulled in multiple and oftentimes competing directions (Trethewey and Ashcraft, 2004). Operating under a larger rubric of 'tension-centered scholarship,' researchers investigate ironies, contradictions, and paradoxes in organizing (Gibbs, 2009; Koschmann and Laster, 2011; Trethewey and Ashcraft, 2004; Smith and Lewis, 2011; Stohl and Cheney, 2001; 
Tracy, 2004). This line of work is important because 'scholarship that denies the powerful presence of tensions neglects the basic character of organizational life' (Ashcraft and Trethewey, 2004: 171). Four processes characterize this approach: paradoxes are 'dilemmas that demand impossible choices between non-existent or mutually exclusive options, e.g. 'be spontaneous" (Gibbs, 2009: 908); tension refers to 'the clash of ideas or principles or actions and to the discomfort that may arise as a result' (Stohl and Cheney, 2001: 354); contradiction arises when two ideas are in mutual opposition to one another; and irony refers to 'a stance toward paradoxes that invites observers and participants at least to realize and perhaps also to transcend the limitations of their own efforts' (Stohl and Cheney, 2001: 354).

Research has explored tensions in consulting and change interventions. Jian (2007) explicated varied tensions that resulted from an information and communication technologies (ICT) program implementation at an information technology company. Although management framed the changes as 'appropriate' and necessary, employees discursively constructed their own, oppositional meanings. Jian's findings point to the ironic consequences of change implementations as well as how organizations operate as 'sites of struggle where different groups compete to shape the social reality of organizations in ways that serve their own interests' (Mumby and Clair, 1997:182). How to manage these struggles is an ethical leadership process.

In summary, ethical leadership has received wide scholarly and popular attention. How to define and implement leadership development, particularly practices drawing attention to productive ethical processes in a highly complex global world, has required different approaches. Over the past decade, CC has gained traction in the business community as a way for companies to reappraise how they do business and positively contribute to society. Although incorporating CC appears a worthwhile aim, it is by no means a panacea, as it is fraught with challenges. Taking a d/Discourse and tension-centered lens, our research seeks to answer the following question (RQ1): What are the tensions and complexities surrounding 
NOT THE PUBLISHED VERSION; this is the author's final, peer-reviewed manuscript. The published version may be accessed by following the link in the citation at the bottom of the page.

the development of ethical leaders in the service of Conscious Capitalism?

\section{Method}

\section{Participants and Context}

"Devenir" is a management consulting firm located in the southwestern United States, with 12 full-time employees and 20 geographically-dispersed contract coaches. For its leadership development, Devenir offers a 52-week Integral Leadership Program (ILP). To form an ILP offering, members of various organizations at different hierarchical levels (e.g., VP of Sales, CEO) are assembled into classes where they receive one-on-one and group executive coaching; bi-weekly teleclasses composed of ILP members and led by a Devenir facilitator; full-day, 10-hour quarterly workshops; and a Web portal containing music and video clips, core practice worksheets, e-journal listservs, and homework. All client tools are integrated into the learning modules that facilitate the development of conscious, ethical leaders.

We believe Devenir serves as an illustrative case because it shares many of the same goals and aims of today's leadership development and change management firms (e.g., strategy, execution, skill development). Although Devenir is a relatively small company, we believe the experiences we uncover will 'be epistemologically in harmony with the reader's experience and thus to that person a natural basis for generalization' (Stake, 2000:19). Moreover, given the current environment in which business takes place, and the importance of organizational ethics and justice in the wake of recent, high-profile crises, Devenir operates in a space that is sorely needed. At the same time, Devenir provides a unique element in the change management/leader development industry, namely, having $\mathrm{CC}$ as the foundation and target of their efforts, and integrating cognitive, moral, and spiritual elements for requisite development and change.

[Citation: Journal/Monograph Title, Vol. XX, No. X (yyyy): pg. XX-XX. DOI. This article is @ [Publisher's Name] and permission has been granted for this version to appear in e-Publications@Marquette. [Publisher] does not grant permission for this article to be further copied/distributed or hosted elsewhere without the express permission from [Publisher].] 
NOT THE PUBLISHED VERSION; this is the author's final, peer-reviewed manuscript. The published version may be accessed by following the link in the citation at the bottom of the page.

\section{Procedures}

After obtaining approval from the Instructional Review Board, the first author engaged in a two-month field study of Devenir, where he was regarded as an intern or 'job shadower.' Wide access to the organization resulted in four data collection methods: (a) 16 semistructured, open-ended interviews with Devenir members and 13 with Devenir clients (over 500 double-spaced pages of transcription); (b) over 500 pages of documents including the company website and client materials (e.g., online interactive coaching software, pamphlets); (c) 100 hours of participant-observation (212 typed, double-spaced pages of field notes); and (d) autoethnographic journaling (120 typed, double-spaced pages).

In line with a discursive approach the researchers became attuned to the stories and realities that comprised Devenir life (Bushe and Marshak, 2009). Accordingly, two different data analyses were performed: constructivist grounded theory (Charmaz, 2006) and critical discourse analysis (Chouliaraki and Fairclough, 2010). First, following Charmaz's method, data collection and analysis occurred simultaneously, such that the first author began to 'separate, sort, and synthesize...data through qualitative coding' (3) in the field. Selection of themes was guided by Owen's (1984) criteria of recurrence, repetition, and forcefulness. During the final two weeks of data collection, the first author took his findings to members to verify, ask further questions, and 'member check' (Lindlof and Taylor, 2011) findings with participants.

Our second data analysis technique, critical discourse analysis (CDA), occurred after the initial constructivist approach. Our constructivist grounded theory approach afforded a data-generative representation of the key themes involved in Devenir's Work, which comprise the first part of our results section (see Table 1, Appendix). Then, CDA allowed us to reflect on our themes further, taking a stance of suspicion and vulnerability to guide our inquiry (Mumby, 1997). Essentially, combining grounded theory and CDA allowed us to uncover surface-level and deeper meanings (i.e., best practices and tensions, respectively). The revealing of multiple layers of meaning is a key aim of our critical study because 'surface level meanings and behaviors

[Citation: Journal/Monograph Title, Vol. XX, No. X (yyyy): pg. XX-XX. DOI. This article is @ [Publisher's Name] and permission has been granted for this version to appear in e-Publications@ Marquette. [Publisher] does not grant permission for this article to be further copied/distributed or hosted elsewhere without the express permission from [Publisher].] 
obscure deep structure conflicts, contradictions, and neuroses that systematically limit the possibilities for the realization of a genuinely democratic society' (Mumby, 1997: 9). In essence, CDA allowed us to be more open to the tensions, complexities, and challenges associated with Devenir's practices. Appropriating critical discourse analysis opened our analysis to issues of power, hegemony, and power relations, while keeping an analytical eye on local texts and wider social practices (i.e., d/Discourses; see Phillips and Oswick, 2012).

\section{Results ${ }^{1}$}

Our findings are organized in two parts: (a) core practices in ethical leader development; and (b) a critical perspective, revealing micro- and macro-level tensions in developing ethical leaders. We first provide a sampling of Devenir's key practices in developing leaders to contextualize the tensions we uncovered in our critical take.

\section{Best Practices in Developing Ethical Leaders}

According to participants, Devenir strives to create seamless mental map of curriculum and training materials, a coherent set of practices for the consultants, and embodied experiences for the clients that they and their clients considered to be effective (for best practice themes, see Table 1, Appendix). Of note are the various ways in which Devenir seeks to position itself vis-à-vis the larger leadership training and consulting industry. Language choices help them to discursively position (Bisel and Barge, 2010; Davies and Harré, 1990) themselves in the leader development and consulting industry. Devenir refers to clients as "partners" to stress long-term relationships. It reinforces a Devenir ecosystem to bring consciousness to businesses and leaders, in the service of CC and a commitment to ethics. Moreover, Devenir works to ensure careful alignment with their partners, only working with clients that: are mid-market in size; have concentrated, private ownership; are physically close to Devenir offices; and share Devenir's values (e.g., a commitment to CC). Insuring alignment functions to secure relationships with partners who have similar mindsets, worldviews, change expectations, and values.

[Citation: Journal/Monograph Title, Vol. XX, No. X (yyyy): pg. XX-XX. DOI. This article is @ [Publisher's Name] and permission has been granted for this version to appear in e-Publications@ Marquette. [Publisher] does not grant permission for this article to be further copied/distributed or hosted elsewhere without the express permission from [Publisher].] 
NOT THE PUBLISHED VERSION; this is the author's final, peer-reviewed manuscript. The published version may be accessed by following the link in the citation at the bottom of the page.

Additionally, Devenir emphasizes a practice-based approach to learning leadership. A common metaphor in Devenir's leadership development work involves working out, or finding new forms of building muscle. Athletics and martial arts references abound. Devenir leadership development is akin to 'getting down on the mat' (as in wrestling) and 'striking a hard surface repeatedly in order to improve bone density.' Devenir members discussed the need to practice-'in the gym,' 'doing the reps'-to transform as leaders. The practice-based approach is designed to cause leaders to be more mindful of their development as leaders, in the same way that health and fitness becomes part of one's daily and lifelong routine. Participants are reminded constantly that a development commitment takes reflection, mindfulness, and deep embodiment of practices. During one telelesson, participants likened a state of mindfulness to the film The Matrix where one is able to slow down time, lean back, and dodge the bullets as they fly overhead. Similarly, one facilitator explained that being mindful is akin to a batter being able to see the stiches on a baseball before making contact. These examples demonstrate the power of a leader to exercise 'slow motion' sensemaking through mindfulness.

Above, we described one firm's discursive and embodied ethical leadership development approach. Devenir's company-wide macrodiscourses, everyday talk, and embodied practices strive to construct and reaffirm a coherent story of effectiveness that seems to be successful in developing leaders' consciousness. Next, we offer a critical take on ethical leadership development, thereby widening our perspective to look at partial and fragmented points of discursive struggle (Alvesson and Deetz, 2000).

\section{Micro- and Macro-Level Tensions in Ethical Leadership Development}

We consider the interplay of micro and macro levels and forms of $d$ /Discourse. In any attempt to develop leaders, 'multiple Discourses comprise the discursive context for organizations and the success or failure of change initiatives will fall partially on the ability of change agents to address the opportunities and constraints created by their discursive context' (Bisel and Barge, 2011: 3). In Devenir, CC operates

[Citation: Journal/Monograph Title, Vol. XX, No. X (yyyy): pg. XX-XX. DOI. This article is @ [Publisher's Name] and permission has been granted for this version to appear in e-Publications@Marquette. [Publisher] does not grant permission for this article to be further copied/distributed or hosted elsewhere without the express permission from [Publisher].] 
as a Discourse of social change and responsibility-its impetus for and target of development. For each finding, we identify a key image that illustrates the tension. These images are meant for illustrative purposes; they help the reader get a sense for what the tension looks like in practice. Our analysis focuses not simply on identifying the tensions, but how the tensions function, and how those experiencing tensions struggle to communicatively resolve and/or balance them (Koschmann and Laster, 2011).

\section{Micro-Level Tensions: Paradoxes of Practice Structuring and Releasing.}

This finding explores an inherent tension involved in leaders' need to follow a disciplined, regimented practice, necessary for true leadership development, according to Devenir, and its unintended consequences. The key image in this part of the story is the tensional struggle between reining in and pushing out. These tensions center on keeping leaders committed to learning and practices (reigning in), while also enabling their strengths in creativity and independence to flourish (pushing out). Laura, a coach, explains:

We're experimenting with how do we incorporate the practice based approach and the supporting structures and get the client to agree to it, because we know that that works, but if they haven't experienced it and our clients for the most part are wild and crazy entrepreneurs that don't have a lot of discipline, entrepreneurs typically don't. What makes entrepreneurs successful is also what typically holds them back from a sustainable company ...the founder might have been some wild and crazy entrepreneur but as the family grows up in that company, they're developing different skills or whatever because a lot of entrepreneurs get really bored with that sustainability part of the business.

In Laura's interview, the notion that entrepreneurs 'get really bored with that sustainability part of the business' is interesting from a leadership perspective. As an organization works toward becoming more ethical and just (i.e., a 'conscious' organization), sustaining leader development is critical if there is ever hope that ethical behavior and fairness might trickle down to the entire organization, as can be 
the case for unethical behavior (Cropanzano and Stein, 2009). In the end, the result is the competing orders of discourse (Fairclough, 1993) among entrepreneurialism (i.e., the entrepreneurial spirit of creativity and independence), structure, and sustainability that Devenir must constantly negotiate in order to develop leaders.

Expanding and contracting. This subtheme explicates how Devenir preaches an expansive and multilayered discourse of being able to transform leaders and organizations and do good in the world through CC, within a limited scope and target audience. The key image here is preaching expansion but practicing reality. Here we explore what it means to talk about changing the world, within the material realities of time, space, and other scarce resources in today's complex business environment. Roger, a co-founding member of Devenir, explained to the first author that his view of what Devenir's purpose is in the world is 'crystal clear':

This business. 'The Work.' ... We have a point of view that evolves but our current point of view is crystal clear. If we believe that, this business is here to participate in the transformation of society, ... [then] there's all sorts of ways to do The Work. Since the conditions that are most ideal for The Work are long term.

Roger notes that Devenir is a small part of societal transformation. In another example, a coach, Parr, in an interview, illustrates the idea of working within a larger space or movement for transformation, where Devenir is 'hopefully well positioned to catch a wave':

And we can tell compelling stories about the difference it makes if you have a view of what leadership is and what organizations are and what's involved in performance and change. You know we have an opportunity to be a part of changing the way that people think about business and organizations and communicate that ...

In positioning Devenir participants as engaging in local change, proponents create a disconnect between micro and global transformation but position participants' personal consciousnessraising as the means for large-scale change. Later in his interview, Roger explained that the way Devenir 'can make the most meaningful

[Citation: Journal/Monograph Title, Vol. XX, No. X (yyyy): pg. XX-XX. DOI. This article is @ [Publisher's Name] and permission has been granted for this version to appear in e-Publications@Marquette. [Publisher] does not grant permission for this article to be further copied/distributed or hosted elsewhere without the express permission from [Publisher].] 
impact the system is to be a part of the revolution outside the palace walls, the mid-market.' In Matt's (coach) interview, he stated his belief that Devenir is an 'agent of evolution' through CC. Yet, the transformational discourse for leaders, business, society, and the world is in tension with the reality of limited size and scope (i.e., individual leader consciousness in mid-market companies).

For Devenir, their commitment is to social change via ethical leaders, businesses, and CC. Devenir has an expansive discourse of boundaryless care and concern for the world; however, they also have niche marketing and strict criteria (e.g., mid-market, privately-held, close headquarters). Their discourses of transformation are limited by their practices and scope. What is revealed through this expandingcontracting tension, as different orders of discourse compete (Fairclough, 1993) (i.e., working for global social change through leadership practices within a very small niche and through personal consciousness) is a pragmatic-idealism, or a sustainability-ideology tension inherent in any organization that is both a business and an advocate for social change (D'Enbeau and Buzzanell, 2011). A key challenge for such organizations is to 'manage the tensions or engage in business efforts that do not damage ideology credibility' ( $D^{\prime}$ Enbeau \& Buzzanell, 2011: 47).

Consequently, Devenir runs head-on into a tension between the purity and idealism of CC and the pragmatics of their business reach. To further illustrate the tension, consider the following example from Matt, a coach, in an interview:

So this environment, Devenir, is one where pushing the limits is done with the most skill, with the most intention. I can't tell you how cool it is to know when you come here, that people's primary intention is doing good in the world. And then they have all these secondary intentions that they enact in spirit, for the client you know for themselves even to benefit themselves or benefit the client. But again, up against a larger backdrop of doing good in the world. You know we call it Conscious Capitalism or whatever you want to call it. But still underlying that it's everybody waking up in the morning and saying to themselves either consciously or unconsciously how can I get up this morning and do some good in the world? 
And then at the same time, not feel like you're with a bunch of namby-pamby you know green folks who are just kind of believing in this ideological world that doesn't you know that can't possibly exist. It's grounded in reality. It's a good old Stockdale paradox which is optimistic absolutely pushing the edge, pushing that progressive edge, really wanting society to evolve, but understanding and fully accepting the systems and processes and mentalities that it's grounded in but always pushing evolution. We all feel as if we're agents of evolution.

Represented in Matt's interview excerpt are notions of pushing out into the unknown, pushing the edge, forging ahead, being 'agents of evolution,' and so on. Matt's comments clearly represent a fundamental tension between idealism and pragmatism: 'not feel like you're with a bunch of namby-pamby you know green folks who are just kind of believing in this ideological world that doesn't you know that can't possibly exist. It's grounded in reality.'

Additionally, Matt's references are consistent with the frontier myth, where a (typically male) heroic character pushes out into the unknown or uncharted territory, while maintaining a commitment to a common good (see Harter, 2004). The frontier myth privileges masculinity insofar as it is characterizes by isolation and independence (Harter, 2004). Further, this type of Renaissance-like heroism is indicative of a "manstory," which is focused on a quest, a linear progress to achieve work success (Gergen, 1990, as cited in Buzzanell \& Lucas, 2006). By contrast, a "womanstory" is concerned with responsibility to wider needs in a larger context and a connection to others (Buzzanell \& Lucas, 2006).

As a result, Devenir leadership calls upon different discourses to make sense of the tension. On the one hand, there is the push for mindfulness and a space for reflection on the purpose of the business (i.e., conscious business); on the other, the pragmatics of running a business and being financially sustainable. These examples provide a glimpse of the ongoing and interactional, communicative constitution of meaning within the larger industry of leader development. Stated differently, the examples are illustrative of the ways in which d/Discourses compete in various ways for organization members (Alvesson \& Kärreman, 2000; Fairclough, 1993; Fairhurst, 2007). Furthermore, the ideology-practicality tension operates as a 'wicked'

[Citation: Journal/Monograph Title, Vol. XX, No. X (yyyy): pg. XX-XX. DOI. This article is @ [Publisher's Name] and permission has been granted for this version to appear in e-Publications@ Marquette. [Publisher] does not grant permission for this article to be further copied/distributed or hosted elsewhere without the express permission from [Publisher].] 
dynamic insofar as the presence of deeply entrenched, incommensurable, intractable conflicts over assumptions and practices that lack clear problem specification and resolution.

\section{Macro-Level Tensions: Paradoxes of Conscious Capitalism}

Opening up and Closing. This theme explores how Devenir might become a closed system once the core group is fostered and folks commit to 'staying there forever.' Furthermore, we uncover potential implications of this closure for their efforts toward CC. The key image in this subtheme is inviting in and keeping out-that which is open, but at the same time closed.

The extent to which Devenir cultivates a core group of employees, clients, and philosophy and becomes a (closed) system that feeds upon itself, stands in stark contrast to the aims of CC. Ironically, part of cultivating an ethical awareness (or consciousness) is being open to and, indeed, aware of, outside influences and sensitive to the complex set of relationships that characterize modern business life. Despite what is found in most (normative) approaches to leadership (see Mihelič et al., 2010; Thompson et al. 2010), ethics require a complex awareness and consciousness rather than simply behavioral modeling or following ethical codes.

Below is an excerpt from field notes recorded while the first author attended a leadership meeting. The topic of discussion is cultivating the core Devenir team:

Justin [a coach] brings up the issue of developing and cultivating Nelson [a new employee] on the team. He is the lowest on the spectrum and he might be at risk for leaving. Justin wonders if his non-financial rewards are enough to keep him on board. Walter [a coach] notes that Devenir is one of the closest you can get to a being able to freelance your work while still being a part of a company.

Roger says he wants to cultivate the core group of people who want to stay there forever. Walter says that they have to not be embarrassed about what they're about. When he goes to integral theory conferences and people are already on tier 2, he

[Citation: Journal/Monograph Title, Vol. XX, No. X (yyyy): pg. XX-XX. DOI. This article is @ [Publisher's Name] and permission has been granted for this version to appear in e-Publications@Marquette. [Publisher] does not grant permission for this article to be further copied/distributed or hosted elsewhere without the express permission from [Publisher].] 
says no. He wants to have tier 1 to tier 2 missionaries, 'preaching the gospel.' (June 25, 2010)

The Work necessitates a core group (community), but ideological proponents want freedom to do 'freelance work' (autonomy). Tensions center on questions such as: how to stick to 'The Work' while having flexibility to challenge knowledge; how to cultivate the core when their work lends itself to freelance opportunities? These findings point to implications regarding creativity and difference in maintaining a carefully vetted group (Kärreman and Alvesson, 2009).

During a leadership meeting, the discussion ensues about selecting new members for the Devenir team. As seen in this field note excerpt, Devenir members discuss very specific criteria:

Walter talks about the importance in having the same vision for what each party wants. He wants someone who worked for a big company but hasn't been in the business so long that they're at a senior level. He says he doesn't want someone who has to unlearn a bunch of stuff. He also says he would love to hire a woman for several reasons, one of which is to add some diversity to the office. Laura mentions a group of women, who might be good, some of whom are Latina. Walter also talks about the fact that they have to recruit the right kind of person who isn't looking to work for 250k per year, because they simply can't keep up with that. He says ideally they would love to have someone who is $\mathrm{C}$ or $\mathrm{B}$ (moderate to higher level of talent, like earning a $\mathrm{C}$ or $\mathrm{B}$ on an exam). Bryce then adds that they become A players with Devenir. (June 25, 2010)

This is a prime example of Devenir members laying out specific criteria to ensure that a new member fits within the core group. They want someone who is appropriate for Devenir. But how can the expansive CC movement be fostered, and considered ethical, by such a homogeneous group and exclusionary language? Walter says that he 'doesn't want someone who has to unlearn a bunch of stuff.' Being highly selective in this manner can be problematic, to the extent that what 'the $\mathrm{C}$ or B-level talent' knows is valuable to furthering the mission of Devenir, which is to develop conscious, ethical leaders and conscious businesses. 
We argue that there are dangers in cultivating such a tight-knit core group that is steeped in specialized language of transformation, such that they are likened to 'missionaries,' 'preaching the gospel,' or 'The Work.' The danger lies in the creation of a closed system, such that there is difficulty in trying to fit the language and practices with the culture of a given organization, creating pushback and tension. Jack, a Devenir client, explains what it looks like when some of the training material fails to hit the mark: 'there was a certain level that a mid-level manager can accept. It got beyond their [capacity], and they're 'okay uh no we can't do that.' Because I was Devenirized. It was like a religious cult. I was in the cult.' Jack becoming 'Devenirized' illustrates the results of discursive hegemony (Laclau and Mouffe, 2001), aptly described by Nabers (2009): '[Hegemony] reproduces our daily life; it starts to be hegemonic when our everyday understanding of social relations and the world as a whole starts to alter according to the framework that is set by the hegemonic discourse' (197).

Furthermore, the notion of the leader being in the 'cult' and 'Devenirized' has implications for the larger organizational culture, and for the leader-member relationships. In Jack's case, his being so wellversed in the language of the 'cult' hampered his ability to lead. Furthermore, in an interview, Jack presents the ironic implications of the (closed) Devenir discourse and mindset when used outside Devenir:

The downside of Devenir is now you know the language, you may go back to your existing relationships. On a business level for me, I would go back to other relationships that I had that I respected them as peers and try now to talk to them and you know, it wasn't the same. I was like 'really you're going to tell me what to do without even listening to me?' I was operating like this for so long why would, you don't even know what my problem is and you just got the answer right away. That's not so and I you know, Roger does ruin you in a certain way.

Jack expects others to listen to him as his Devenir colleagues do. But now he finds that he cannot talk to old friends or respect them as peers. He is 'ruined' and expresses his fit only in Devenir. In the interview, Jack's discomfort with this lack of fit was evident in his tone and the forcefulness with which he described it. 
NOT THE PUBLISHED VERSION; this is the author's final, peer-reviewed manuscript. The published version may be accessed by following the link in the citation at the bottom of the page.

An example from an all-day leader training workshop further illustrates how Devenir's practices resemble a closed system, leading to discursive closure (Deetz, 1992). At the beginning the workshop, the co-facilitator, Roger, asked participants to share their take-aways from a dinner they had had the night before. One of the participants shared his take-away, saying, 'there is a real desire right now to find a deeper purpose. The challenge is, as a leader, how do you craft a message that everyone buys in to?' Roger responded to these comments from participants: 'Roger says that what they are sharing is insightful because they are discussing problems and the struggles. He says that they are not here today to solve problems; they are here to experience things-struggle through the struggles together' (field notes, July 15, 2010). At the end of the workshop, while participants discussed their key take-aways from the day, one of the participants stood up and said he has been out of his comfort zone all day. Roger responded, saying that 'it is a learning experience and that it is good that they are in the community together, struggling through these issues' (field notes, July 15, 2010). The result is that any challenges are discursively closed off and co-opted into the learning, as leaders learn to see things the 'Devenir way.' This example demonstrates the final step in discursive hegemony: 'the discourse produces specific practices and institutions. It acquires material objectivity by becoming institutionally fixed' (Nabers, 2009: 197). Furthermore, this provides an example of how ethics are embedded within language practices and power (see Gordon et al., 2009).

Collaborating and competing. Some of Devenir's practices can undermine CC. The key image here is working together and differentiating-talking collaboration, fostering competition.

As an expansive discourse, CC is about 'integrity, transparency, enlightened governance' (Aburdene, 2005: 5), and free markets, entrepreneurship, competition, freedom to trade, property rights, and the rule of law. Advocates recognize that these are essential elements of a healthy, functioning economy, as are trust, compassion, collaboration, and value-creation ('Conscious Capitalism,' 2012). Here is where the $d / D i s c o u r s e s$ become problematic. Might the ethics of care and reflection in $\mathrm{CC}$ be undercut by an 'unapologetic' advocacy for free market competition? 
NOT THE PUBLISHED VERSION; this is the author's final, peer-reviewed manuscript. The published version may be accessed by following the link in the citation at the bottom of the page.

Devenir uses competition-based, masculine references to frame their material. Consider the appropriation of sports and martial arts metaphors. Transformation was likened to 'getting on the mat,' 'training the holes in one's game,' and 'doing the reps' until 'dense bones and calluses form' from 'striking up against a hard surface,' as in martial arts. Similarly, development, growth, and transformation were compared to familiar literary references, all with competitive, masculine-based overtones. In an interview, Roger connected sports and literary references to discuss the transformation Tiger Woods went through in changing his swing several years ago:

So imagine being the best in the world at something and then telling the world, 'I'm going to reinvent my winning formula'. The world attacked him and said 'why would you do that? You're the best in the world'. And he said, paradox, 'it's the very swing that got me here that's now has been holding me back, so I have to reinvent'.

... His performance was down. ... His body was getting reinvented from small to big. Then he took steps forward and gets even better. This is unheard of in our culture. This is the hero's journey. This is the journey of Luke Skywalker. This is Joseph Campbell's myth, ok? This is Beowulf.

Here, we question whether these references undermine principles of CC (e.g., care, concern, collaboration, ethics). Specifically, what does it do to the mindset of leaders to think using Joseph Campbell's hero's journey, Beowulf, and Luke Skywalker fighting Darth Vader as their frames of reference? John Mackey (2011), a principal proponent of CC says that thinking in terms of winning and losing, in zero-sum terms is problematic for any effort toward social justice. It would seem that sports metaphors represent and foster zero-sum thinking par excellence. This is also further evidence of a "manstory" (Gergen, 1990, as cited in Buzzanell and Lucas, 2006).

For Devenir, they seem to be moderately aware of the implications of the tension between their aims and the masculine discourse. For example, participation by females is extremely low, an issue of which they are recently aware. At an event where the first author observed, one of the female participants who was a potential client asked what percentage of females had completed the ILP.

[Citation: Journal/Monograph Title, Vol. XX, No. X (yyyy): pg. XX-XX. DOI. This article is @ [Publisher's Name] and permission has been granted for this version to appear in e-Publications@Marquette. [Publisher] does not grant permission for this article to be further copied/distributed or hosted elsewhere without the express permission from [Publisher].] 
Unsure of the answer at the time, the first author subsequently received the numbers via email. As of August of 2010, 21 of 147 ILP graduates $(14 \%)$ have been female. ${ }^{2}$ The percentage of women in the ILP is low compared to the percentage of women found in privatelyowned businesses, Devenir's target market.

Here, as in the last section, we believe this signals discursive hegemony (Laclau and Mouffe, 2001) whereby the discourse of competition wins out over that of care, collaboration, and concern. The danger of such hegemony is that, over time, the microdiscursive practices designed to develop leaders to be more ethical could undermine the efforts toward social change, in the same way that gain (and greed) trumped Enron's and others' (e.g., Lehman Brothers) efforts toward social responsibility. Furthermore, this finding illustrates the 'wicked' problems inherent in combining ethical leadership development with a CC agenda. Specifically, the consultants and leaders simultaneously appropriate the language of capitalism (i.e., competition, free markets) while trying to subvert it in some ways through a focus on mindfulness, care, and concern. However, we argue that this subversion is necessary but insufficient for dealing with the ideological constructions that promote dominant power interests.

\section{Discussion}

At the heart of Devenir's philosophy and practice is both the goal of effectiveness, progress, and development grounded in modernism and individual/organizational development efforts; and the goal of societal and global transformation based on Conscious Capitalism. This analysis 'showcase[s] one of the many interpretations that might be useful in terms of understanding, liberating, and/or empowering' (Wendt, 1998: 333). Indeed, we can learn a lot from describing the coherent, pragmatic tale of best practices and normative ethics; but our critical perspective, with its openness to the mysterious and unexpected (Spicer et al., 2009), goes further to reveal less-than-coherent tales, in a less-than-coherent world. Through critique of everyday practices couched within popular and scholarly enthusiasm for positive change we reveal how the quest for ethical leadership and societal transformation can result in a fascination with positive processes and outcomes, leading to first-level 
benefits (e.g., leadership competencies, work-life balance, increased profits), but long-term exclusionary practices (e.g., cultivating a homogeneous group, failing to grapple with structural problems of capitalism).

Our research provides a framework that other scholars can use to engage with other popular discourses of social change. Although empirical research has begun to explore Social Entrepreneurship (e.g., Dempsey \& Sanders, 2010; Fayolle \& Matlay, 2010), it would be insightful to explore the inherent tensions and complexities that might arise in working for social change for social entrepreneurs and their organizations. Furthermore, as organizations such as Ashoka, the world's largest organization dedicated to Social Entrepreneurship, continue to develop networks of like-minded social change agents, research should explore the impact of these messages on the social entrepreneurs and their efforts. Finally, the same critical approach could be applied to a newly-emerging perspective on social change known as collective action, whereby cross-sector collaboration is key to driving change (Kania \& Kramer, 2011).

Moreover, this research project explores CC as a newly emerging Discourse worthy of consideration. As movements such as CC continue to take shape and receive popular attention, it is important that researchers examine these Discourses of social change. Indeed, CC is akin to 'social entrepreneurship,' 'strategic philanthropy,' and 'corporate social responsibility'; terms that together lack a natural fit, thereby opening them up to critique (see Roper \& Cheney, 2005). At CC's core is a struggle against unbridled greed and political economic systems that advantage few in a turbulent global world; CC represents a struggle against the 'wicked problems' (see Fairhurst, 2011; Rittel and Weber, 1973) that leaders and businesses face. Such struggles are made visible through quests for transcendent human values, deeper business purposes beyond profit maximization, and refinements of capitalist systems.

Despite CC's promises, we discovered tensions that can undermine its effectiveness. At the most fundamental level, we reveal an inherent contradiction within CC-the need for efficiency, profit, and pragmatism appears antithetical to hope for a more humane form of 
capitalism. At capitalism's core is free-market, capital accumulation, and voluntary trade. Capitalism naturally leads to an emphasis on profit maximization as the purpose of business (Friedman, 1970), as capitalists 'find themselves chained to a never-ending and insatiable process' (Chiapello and Fairclough, 2002: 186). Given the acceptance of capitalism as the way to go, with CC as an alternate form, Conscious Capitalists fail to grapple with its ideological inconsistencies. Ironically, therefore, despite a leadership development program's best intentions, these programs could actually further reinforce and promote emphasis on "traditional" capitalism over conscious capitalism. Whether or not CC is a viable "alternative" to traditional capitalism remains to be seen. However, CC proponents do point to successful organizations that operate more consciously (e.g., Whole Foods, Patagonia, Southwest Airlines ${ }^{3}$ ), for their focus on stakeholder relationships, environment, conscious cultures, and so on.

We show how attempts to develop ethical, just leaders can reinforce problematic assumptions of capitalism, leading to mindless processing in the name of efficiency. Indeed, although there is a sampling of places where consultants and participants might be aware of the tensions we identified (e.g., Matt's comments about being ruined, the lack of female participants), our evidence leads us to conclude that the tensions are not addressed head-on. For example, although female participation in their programs is low, we could not find any evidence that they were aware of how their practices might undermine their aims. Using CDA, we opened up our analysis to evidence of discursive hegemony (Laclau and Mouffe, 2001), whereby certain d/Discourses won out over others in the effort to develop ethical leaders and affect social change. In this way, a purely capitalistic ideology was produced and reproduced in the process of interactions (Edwards, 2006; Burawoy, 1979) between consultants and clients. Discursive hegemony is a theoretically useful concept to apply in conjunction with CDA to explore different orders of discourse (see Chiapello and Fairclough, 2002; Nabers, 2009).

Ironically, despite CC's approach to handling ethical dilemmas, framing leader development in the service of CC is itself a wicked problem. Although Devenir takes steps to teach techniques such as reflection (Pacanowsky, 1995) and reframing (Fairhurst, 2011), the 
unintended consequences and tensions can lead to wider-ranging problems than imagined. As with wicked problems, solutions can lead to further problems (see Grint, 2005). Our critique demonstrates how solutions can exacerbate ethical dilemmas (e.g., creation of exclusionary practices despite promises of transformation).

Thus, our findings extend ethical leadership development approaches to wicked problems (Fairhurst, 2011; Fairhurst and Grant, 2010; Grint, 2005; Rittel and Weber, 1973). As demonstrated, microlevel practices can belie the aims of the macro-level Discourse. Our results provide a framework for exploring tensions at multiple levels in a given d/Discursive context. Our combination of multiple levels of discourse avoids the dichotomization commonly found in studies that emphasize one d/D over another (Phillips and Oswick, 2012). As organizations are increasingly called upon to tackle complex and wicked social problems, researchers must explore how the ' $d$ 'iscursive practices can exacerbate the aims contained in the Discourse.

Our findings illustrate the deeply embedded nature of wicked problems. It is not just the problem that surfaces but the leaders' responses that hold fundamental incompatibilities that fail to delve into deep causes and that exacerbate the issues. Leaders have multiple subjectivities and interests, but it appears that the force of capitalism often overrides other subjectivities and invocations of macrodiscourses that can combat capitalistic tendencies (i.e., CC). In our study, neither the trainers nor leaders carved out spaces for resistance and allowed themselves to see these incompatibilities. Ironically, despite the push for mindfulness, the leaders failed to see how linguistic practices led to mindless acceptance of dominant ideologies. Indeed, the leaders have agency, but with wicked problems individuals have a difficult time determining how their agency might be best directed. Moreover, the taken-for-granted nature of ideological formations means a failure to consider different routes. In the end the types of leaders being developed are those that accept capitalistic tendencies at face value.

Therefore, this research also contributes evidence of the tensions and complexities involved in cultivating mindfulness. Although some research explores the role of mindfulness in decision making (see Krieger, 2005; Novak and Sellnow, 2009), the role of mindfulness 
in ethical leadership development is unknown. As a Discourse of positive social change, $\mathrm{CC}$ is based in notions of mindfulness, enhanced attention to the world, and active processing of stimuli (i.e., leaders being highly aware and spiritually evolved). As a psychological process, mindfulness links knowledge and behavior. However, given the speed with which leaders are asked to make decisions today, it is highly possible (and pragmatic) to be mindful of some aspects of decisions and behaviors and mindless or engaged in habitual processing about others. Thus, despite leaders' mindfulness of the values imbedded in the CC Discourse, they may not see how everyday habitual behaviors and ways of thinking perpetuate capitalistic tendencies.

Finally, this research contributes to the literature on organizational justice and behavioral ethics. CC can have ripple effects that directly affect justice and ethics for an organization at multiple levels. For example, an organization employing CC as a model for its culture and business practices could be more likely to ensure processes that are just, because of the presence of leaders who adhere to higher ethical standards. Despite the fact that organizational justice and behavioral ethics have only recently begun to engage with each other (Cropanzano and Stein, 2009), we believe that our analysis shows a fruitful framework for engagement with the two.

Similarly, our discussion of mindfulness connects to justice and ethics. In brief, mindfulness affects the health and well-being of individuals and, by extension, would help an organizational culture if leaders model and encourage others to be open to novelty and sensitive to perspectives and context (for an overview of applications of mindfulness to various disciplines, see Demick, 2000). In fact, Demick (2000) argues that mindfulness theory has the potential to help 'conceptualize problems that are more in line with the complex character of everyday life' (155). Further research is needed to explore the implications of mindfulness on such complex problems as ethics and organizational justice.

Pragmatically, we argue that the value of CC extends beyond organizational change and leader development. Consider, for example, that such services as Devenir's are only available to a select group of 
people (e.g., businesspeople with sufficient monetary resources). What benefits exist if we could extend these messages of CC (e.g., care, collaboration, positive change) out into the community? One such possibility is to host open community discussion forums around CC. Ultimately, it might serve to expand an already well-designed mental map of training materials.

In addition, our findings indicate pragmatic implications for entrepreneurial programs in education. CC may not be the panacea or a new business paradigm (Mackey, 2009) but it should be examined further. Currently, universities such as Bentley University in Boston, Massachusetts, are spearheading such efforts several ways (e.g., conferences, business courses). Furthermore, it opens up an avenue for critical work, much in the same way that schools offer critical perspectives on CSR courses. We envision pedagogical techniques such as case studies being used, for example, that engage with CC ideals, leadership development, and decision making, and many of the wicked problems that arise. The idea behind such engagement is that as Discourses gain traction in the business world, it is important for students, as part of their socialization into their careers, to engage in critical thinking on these ideologies.

We encourage additional research centered on embodied practice, workshops, and interviews with additional stakeholders to redress limitations in our study. Although the first author was deeply immersed in the day-to-day operations at Devenir, his relatively limited time in Devenir gave him access to only two full-day training workshops. Additionally, the small number of interviews with contract coaches is a limitation. Most interviews were with full-time Devenir members (e.g., Managing Director, Enrollment Lead) and coaches. Devenir has a number of contract coaches (approximately 20) whose perspectives would have been helpful because of their partial emersion into Devenir thinking and behaving.

In sum, 'The Work' of Devenir's everyday leadership development practices differs little from other leader/organization change efforts-there are inspirational talks, telelessons, group work, practice sessions, prereadings, and other activities. The training is long-term, developmental, and embodied-one is encouraged to live, 
breathe, speak, and feel the power of CC in all aspects of life, but particularly in business settings. To become part of the Devenir CC network is to become a member of a select group that can support sustainable change efforts and ideological attacks. However, the other side of leadership development through Devenir is based on paradox and questions. It operates at the margins of conventional thought and practice, within idealism/pragmatism, at individual/collective levels, in inclusionary/exclusionary processes, and with straightforward and paradoxical dynamics to change leaders and the world.

From both sides come lessons (Wendt, 1998) and contributions for business ethics, organizational justice, leadership development, and for efforts toward achieving societal transformation. Accepting systems such as CC at face value without engaging in critique keeps ethical leadership development and lifelong learning in this area at the surface level of normative perspectives and best practices. Our findings suggest we consider positive social change and ethical leader development further in light of unintended consequences and complexities.

\section{References}

Aburdene P (2005) Megatrends 2010: The rise of Conscious Capitalism. Charlottesville, VA: Hampton.

Akrivou K, Bourantas D, Mo S and Papalois E (2011) The sound of silence--A space for morality? The role of solitude for ethical decision making. Journal of Business Ethics 102: 119-33.

Alvesson M and Deetz S (2000) Doing critical management research. London: Sage.

Alvesson M and Kärreman D (2000) Varieties of discourse: On the study of organizations through discourse analysis. Human Relations 53: 112549.

Alvesson M and Kärreman D (2011a) Decolonizing discourse: Critical reflections on organizational discourse analysis. Human Relations 64(9): 1121-46.

Alvesson M and Kärreman D (2011b) Organizational discourse analysis - well done or too rare?: A reply to our critics. Human Relations 64: 11931202.

Ashcraft KL and Trethewey A (2004) Developing tension: An agenda for applied research on the "organization of irrationality." Journal of Applied Communication Research 32: 171-181. 
NOT THE PUBLISHED VERSION; this is the author's final, peer-reviewed manuscript. The published version may be accessed by following the link in the citation at the bottom of the page.

Avolio BJ and Gardner WL (2005) Authentic leadership development: Getting to the root of positive forms of leadership. Leadership Quarterly 16: 315-38.

Barling J, Weber T and Kelloway EK (1996) Effects of transformational leadership training on attitudinal and financial outcomes: A field experiment. Journal of Applied Psychology 81: 827-32.

Bies RJ and Greenberg J (2002) Justice, culture, and corporate image: The swoosh, the sweatshops, and the sway of public opinion. In Gannon MJ and Newman KL (eds.) Handbook of Cross-Cultural Management. Oxford, UK: Blackwell, 320-34.

Bisel RS and Barge JK (2011) Discursive positioning and planned change in organizations. Human Relations 64: 257-83.

Brown ME (2007) Misconceptions of ethical leadership: How to avoid potential pitfalls. Organizational Dynamics 36: 140-55

Brown ME and Mitchell MS (2010) Ethical and unethical leadership: Exploring new avenues for future research. Business Ethics Quarterly 20: 583616.

Brown ME and Treviño LK (2006) Ethical leadership: A review and future directions. The Leadership Quarterly 17: 595-616.

Brown ME, Treviño LK, and Harrison D (2005) Ethical leadership: A social learning perspective for construct development and testing. Organizational Behavior and Human Decision Processes 97: 117-34.

Burawoy M (1979) Manufacturing consent: Changes in the labor process under monopoly capitalism. Chicago: University of Chicago Press.

Bushe GR and Marshak RJ (2009) Revisioning organization development: Diagnostic and dialogic premises and patterns of practice. Journal of Applied Behavioral Science 45: 348-68.

Buzzanell PM and Lucas K (2006) Gendered stories of career: Unfolding discourses of time, space, and identity. In BJ Dow and JT Wood (eds.), The Sage Handbook of Gender and Communication. Thousand Oaks: Sage, 161-178.

Cameron KS, Dutton JE and Quinn RE (eds.) (2003). Positive organizational scholarship: Foundations of a new discipline. San Francisco: BarrettKoehler Publishers.

Camillus JC (2008, May) Strategy as a wicked problem. Harvard Business Review 86: 98-106.

Charmaz K (2006) Constructing grounded theory: A practical guide through qualitative analysis. London: Sage.

Chiapello E and Fairclough N (2002) Understanding the new management ideology: A transdisciplinary contribution from critical discourse analysis and new sociology of capitalism. Discourse \& Society 13(2): 185-208.

[Citation: Journal/Monograph Title, Vol. XX, No. X (yyyy): pg. XX-XX. DOI. This article is @ [Publisher's Name] and permission has been granted for this version to appear in e-Publications@Marquette. [Publisher] does not grant permission for this article to be further copied/distributed or hosted elsewhere without the express permission from [Publisher].] 
NOT THE PUBLISHED VERSION; this is the author's final, peer-reviewed manuscript. The published version may be

accessed by following the link in the citation at the bottom of the page.

Chouliaraki L and Fairclough N (2010) Critical discourse analysis in organization studies: Towards an integrationist methodology. Journal of Management Studies 47: 1213-18.

Conscious Capitalism (2012) What is Conscious Capitalism? Available at www.consciouscapitalism.org.

Cropanzano R, Goldman B and Folger R (2003) Deontic justice: The role of moral principles in workplace fairness. Journal of Organizational Behavior 24: 1019-24.

Cropanzano R and Stein JH (2009) Organizational justice and behavioral ethics: Promises and prospects. Business Ethics Quarterly 19: 193233.

Cunliffe AL (2009) The philosopher leader: On relationalism, ethics, and reflexivity-a critical perspective to teaching leadership. Management Learning 40: 87-101.

Davies B \& Harré L (1990) Positioning: The discursive production of selves. Journal for the Theory of Social Behavior 20: 43-63.

Deetz S (1992) Democracy in an age of corporate colonization. Albany, NY: State University of New York Press.

Demick J (2000) Toward a mindful psychological science: Theory and application. Journal of Social Issues 56: 141-59.

Dempsey SE and Sanders ML (2010) Meaningful work?: Nonprofit marketization and work/life imbalance in popular autobiographies of social entrepreneurship. Organization 17: 437-459.

D'Enbeau S and Buzzanell PM (2011) Selling (out) feminism: Sustainability of the ideology-viability tensions in a competitive marketplace. Communication Monographs 78: 27-52.

Edwards P (2006) Power and ideology in the workplace: Going beyond even the second version of the three-dimensional view. Work, Employment and Society 20: 571-581.

Fairclough N (1993) Critical discourse analysis and the marketization of public discourse: The universities. Discourse and Society 4: 133-68.

Fairhurst GT (2007) Discursive leadership: In conversation with leadership psychology. Los Angeles: Sage.

Fairhurst GT (2009) Considering context in discursive leadership research. Human Relations 62: 1607-33.

Fairhurst GT and Grant D (2010) The social construction of leadership: A sailing guide. Management Communication Quarterly 24: 171-210.

Fayolle A and Matlay H (2010) Handbook of research on social entrepreneurship. Cheltenham, UK: Edward Elgar Publishing Limited.

FLOW Overview (n.d.) Welcome to freedom lights our world! Available at: http://www.flowidealism.org/index-project.html.

Folger R, Cropanzano R and Goldman B (2005) Justice, accountability, and moral sentiment: The deontic response to 'foul play' at work. In

[Citation: Journal/Monograph Title, Vol. XX, No. X (yyyy): pg. XX-XX. DOI. This article is @ [Publisher's Name] and permission has been granted for this version to appear in e-Publications@ Marquette. [Publisher] does not grant permission for this article to be further copied/distributed or hosted elsewhere without the express permission from [Publisher].] 
NOT THE PUBLISHED VERSION; this is the author's final, peer-reviewed manuscript. The published version may be accessed by following the link in the citation at the bottom of the page.

Greenberg J and Colquitt J (eds.) Handbook of Organizational Justice. Mahwah, NJ: Lawrence Erlbaum, 215-45.

Folger R and Salvador R (2008) Is management theory too 'self-ish'? Journal of Management 34: 1127-51.

Folger R and Skarlicki DP (2008) The evolutionary bases of deontic justice. In Gilliland SW, Steiner DD and Skarlicki DP (eds.) Justice, Morality, and Social Responsibility. Charlotte, NC: Information Age Publishing, 2962.

Friedman M (1970) The social responsibility of business is to increase profits. The New York Times, 13 September.

Gibbs J (2009) Dialectics in a global software team: Negotiating tensions across time, space, and culture. Human Relations 62: 905-35.

Gordon R, Clegg S and Kornberger M (2009) Embedded ethics: Discourse and power in the New South Wales Police Service. Organization Studies 30: 73-99.

Grint K (2005) Problems, problems, problems: The social construction of 'leadership.' Human Relations 58: 1467-94.

Harter LM (2004) Masculinity(s), the agrarian frontier myth, and cooperative ways of organizing: Contradictions and tensions in the experience and enactment of democracy. Journal of Applied Communication Research 32: $89-118$.

Jian G (2007) "Omega is a four-letter word": Toward a tension-centered model of resistance to information and communication technologies. Communication Monographs 74: 517-40.

Kania J and Kramer M (2011) Collective impact. Stanford Social Innovation Review 43: 1-6.

Kärreman D and Alvesson M (2009) Resisting resistance: Counter-resistance, consent and compliance in a consultancy firm. Human Relations 68(8): 1115-44.

Kenny K (2010) Beyond ourselves: Passion and the dark side of identification in an ethical organization. Human Relations 63: 857-73.

Krieger JL (2005) Shared mindfulness in cockpit crisis situations: An exploratory analysis. Journal of Business Communication 42(2): 13567.

Koschmann M and Laster NM (2011) Communicative tensions of community organizing: The case of a local neighborhood association. Western Journal of Communication 75: 28-51.

Kuhn T and Ashcraft KL (2003) Corporate scandal and the theory of the firm: Formulating the contributions of organizational communication studies. Management Communication Quarterly 17: 20-57.

Laclau E and Mouffe C (2001) Hegemony and socialist strategy (2nd ed.). London: Verso.

[Citation: Journal/Monograph Title, Vol. XX, No. X (yyyy): pg. XX-XX. DOI. This article is @ [Publisher's Name] and permission has been granted for this version to appear in e-Publications@ Marquette. [Publisher] does not grant permission for this article to be further copied/distributed or hosted elsewhere without the express permission from [Publisher].] 
NOT THE PUBLISHED VERSION; this is the author's final, peer-reviewed manuscript. The published version may be

accessed by following the link in the citation at the bottom of the page.

Larsson M and Lundholm SE (2010) Leadership as work-embedded influence:

A micro-discursive analysis of everyday interaction in a bank.

Leadership 6(6): 159-94.

Lindlof TR and Taylor BC (2011) Qualitative communication research methods (3rd ed). Thousand Oaks, CA: Sage.

Mackey J (2009) Creating a new paradigm for business. In Strong M (ed) Be the solution: How Entrepreneurs and Conscious Capitalists Can Solve all the World's Problems. Hoboken, NJ: John Wiley \& Sons, 73-114.

Mackey J (2011) What is it that only I can do? Harvard Business Review 89: 118-23.

Marshak RJ and Grant D (2008) Organizational discourse and new organization development practices. British Journal of Management 19: S7-S19.

McCann J and Holt R (2009) Ethical leadership and organizations: An analysis of leadership in the manufacturing industry based on the perceived leadership integrity scale. Journal of Business Ethics 87: 211-20.

Mihelič KK, Lipičnik B and Tekavčič M (2010) Ethical leadership. International Journal of Management \& Information Systems 14(5): 31-41.

Mumby DK (2005) Theorizing resistance in organization studies: A dialectical approach. Management Communication Quarterly 19: 19-44.

Mumby DK and Clair RP (1997) Organizational discourse. In van Dijk TA (ed) Discourse as Social Interaction. London: Sage, 181-205.

Nabers D (2009) Filling the void of meaning: Identity construction in U.S. foreign policy after September 11, 2001. Foreign Policy Analysis 5: 191-214.

Novak JM and Sellnow TL (2009) Reducing organizational risk through participatory communication. Journal of Applied Communication Research 37: 349-73.

Owen WF (1984) Interpretive themes in relational communication. Quarterly Journal of Speech 70: 274-87.

Pacanowsky M (1995) Team tools for wicked problems. Organizational Dynamics 23: 36-51.

Phillips N and Oswick C (2012) Organizational discourse: Domains, debates, and directions. The Academy of Management Annals 6: 1-47.

Putnam L, Grant D, Michelson G and Cutcher L (2005) Discourse and resistance: Targets, practices, and consequences. Management Communication Quarterly 19: 5-18.

Rittel HW and Webber MW (1973) Dilemmas in a general theory of planning. Policy Sciences 4: 155-69.

Roper J and Cheney G (2005) Leadership, meaning and human resource management: The meanings of social entrepreneurship today. Corporate Governance 5: 95-104.

[Citation: Journal/Monograph Title, Vol. XX, No. X (yyyy): pg. XX-XX. DOI. This article is @ [Publisher's Name] and permission has been granted for this version to appear in e-Publications@ Marquette. [Publisher] does not grant permission for this article to be further copied/distributed or hosted elsewhere without the express permission from [Publisher].] 
NOT THE PUBLISHED VERSION; this is the author's final, peer-reviewed manuscript. The published version may be accessed by following the link in the citation at the bottom of the page.

Rubin RS, Dierdorff EC and Brown ME (2010) Do ethical leaders get ahead?: Exploring ethical leadership and promotability. Business Ethics Quarterly 20: 215-36.

Rupp DE and Bell CM (2010) Extending the deontic model of justice: Moral self-regulation in third-party responses to injustice. Business Ethics Quarterly 20(1): 89-106.

Schweitzer M, Ordonez L and Douma B (2004). Goal setting as a motivator of unethical behavior. Academy of Management Journal 47: 422-32.

Seeger MW and Kuhn T (2011) Communication ethics and organizational contexts: Divergent values and moral puzzles. In Cheney G, May S and Munshi D (eds) The Handbook of Communication Ethics, New York, NY: Routledge, 166-89.

Seeger MW and Ulmer RR (2003) Explaining Enron: Communication and responsible leadership. Management Communication Quarterly 17: 5884.

Seo M, Putnam LL and Bartunek JM (2004) Dualities and tensions of planned organizational change. In Poole MS and Van de Ven AH (eds) Handbook of Organizational Change and Innovation. Oxford: Oxford University Press, 73-107.

Sivakumar S (2011). What business should do about Occupy Wall Street. Harvard Business Review 24 October. Available at: http://blogs.hbr.org/cs/2011/10/take_the_occupy_wall_street_mo.ht $\mathrm{ml}$.

Smith WK and Lewis MW (2011). Toward and theory of paradox: A dynamic equilibrium model of organizing. Academy of Management Review 36: 381-403.

Spicer A, Alvesson, M and Kärreman D (2009) Critical peformativity: The unfinished business of critical management studies. Human Relations, 62: $537-560$.

Stake RE (2000) The case study method in social inquiry. In Gomm R, Hammersley M and Foster P (eds.) Case Study Method. London: Sage, 19-27.

Stohl C and Cheney G (2001) Participatory processes/paradoxical practices: Communication and the dilemmas of organizational democracy. Management Communication Quarterly 14: 349-407.

Strong M (2009) Be the solution: How entrepreneurs and conscious capitalists can solve all the World's problems. Hoboken, NJ: John Wiley \& Sons.

Thompson KJ, Thach EC and Morelli M (2010). Implementing ethical leadership: Current challenges and solutions. Insights to a Changing World Journal 4: 107-30.

Toor SR and Ofori G (2009) Ethical leadership: Examining the relationships with full range leadership model, employee outcomes, and organizational culture. Journal of Business Ethics 90: 533-47.

[Citation: Journal/Monograph Title, Vol. XX, No. X (yyyy): pg. XX-XX. DOI. This article is @ [Publisher's Name] and permission has been granted for this version to appear in e-Publications@ Marquette. [Publisher] does not grant permission for this article to be further copied/distributed or hosted elsewhere without the express permission from [Publisher].] 
NOT THE PUBLISHED VERSION; this is the author's final, peer-reviewed manuscript. The published version may be accessed by following the link in the citation at the bottom of the page.

Tracy SJ (2004) Dialectic, contradiction, or double bind?; Analyzing and theorizing employee reactions to organizational tension. Journal of Applied Communication Research 32: 119-46.

Trethewey A and Ashcraft KL (2004) Practicing disorganization: The development of applied perspectives on living with tension. Journal of Applied Communication Research 32: 81-88.

Treviño LK, Brown M and Hartman LP (2003). A qualitative investigation of perceived executive ethical leadership: Perceptions from inside and outside the executive suite. Human Relations 56: 5-37.

Visser W (2011) The age of responsibility: CSR 2.0 and the New DNA of Business. West Sussex, UK: John Wiley \& Sons.

Waddock S and McIntosh M (2011) Business unusual: Corporate responsibility in a 2.0 World. Business and Society Review 116: 303-30.

Wendt RL (1998) The sound of one hand clapping: Counterintuitive lessons extracted from paradoxes and double binds in participative organizations. Management Communication Quarterly 11: 323-371 
NOT THE PUBLISHED VERSION; this is the author's final, peer-reviewed manuscript. The published version may be accessed by following the link in the citation at the bottom of the page.

\section{Appendix}

\section{Table 1: Summary of Best Practice Themes and Subthemes}

\begin{tabular}{|c|c|c|}
\hline Themes/subtheme & Definition of theme & Function of theme \\
\hline Discursive positioning & $\begin{array}{l}\text { Ongoing language use } \\
\text { or practice that makes a } \\
\text { person's actions intelligible } \\
\text { and determinate as social } \\
\text { acts within which actors have } \\
\text { specific locations }\end{array}$ & $\begin{array}{l}\text { Carves out a specific niche } \\
\text { within which to locate } \\
\text { themselves within the } \\
\text { larger field of consulting } \\
\text { and leadership development }\end{array}$ \\
\hline $\begin{array}{l}\text { Subtheme: Positioning } \\
\text { through linguistic } \\
\text { choices }\end{array}$ & $\begin{array}{l}\text { Ongoing effort to carefully use } \\
\text { language through two primary } \\
\text { examples: (a) expunging } \\
\text { the word 'consulting'; and } \\
\text { (b) referring to 'clients' as } \\
\text { 'partners' }\end{array}$ & $\begin{array}{l}\text { Enables Devenir to (a) } \\
\text { accurately portray the } \\
\text { type of work they want to } \\
\text { perform; and (b) secure } \\
\text { long-term relationships } \\
\text { with clients }\end{array}$ \\
\hline $\begin{array}{l}\text { Subtheme: Positioning } \\
\text { through practice }\end{array}$ & $\begin{array}{l}\text { Ongoing effort to demonstrate } \\
\text { the importance of a practiced- } \\
\text { based approach to leadership } \\
\text { to set Devenir's approach } \\
\text { apart from (a) knowledge- }\end{array}$ & $\begin{array}{l}\text { Gets 'partners' in the right } \\
\text { mindset that any type of } \\
\text { change and transformation } \\
\text { is difficult and requires } \\
\text { great effort }\end{array}$ \\
\hline
\end{tabular}

based approaches; or (b)

weekend-seminar-style,

single-shot approaches, both

perpetuated in the media

Subtheme: Positioning

Ongoing, careful selection of

clients that (a) are mid-market;

through alignment

(b) are privately owned: (c)

are physically close to Devenir

offices; and (d) share similar

values as Devenir

Discourse as a

strategic resource

Ongoing attempt to

strategically and creatively (a)

align change and development

initiatives with the interests

of the participants; and (b)

illustrate and concretize core practices

Subtheme: Athletic references as strategic

Ongoing effort to employ analogies and metaphors from sports (e.g. baseball, discourse basketball) and martial arts (e.g. Aikido)

Subtheme: Film references as strategic Ongoing incorporation of analogies and examples that demonstrate the connection between Devenir curriculum Secures relationships with partners with similar mindsets, worldviews, values (e.g. long-term horizon, commitment to Conscious Capitalism) Translates interests and helps material 'stick' in the minds of participants

and popular films (e.g. The

Matrix, 12 Angry Men).

[Citation: Journal/Monograph Title, Vol. XX, No. X (yyyy): pg. XX-XX. DOI. This article is @ [Publisher's Name] and permission has been granted for this version to appear in e-Publications@Marquette. [Publisher] does not grant permission for this article to be further copied/distributed or hosted elsewhere without the express permission from [Publisher].] 
NOT THE PUBLISHED VERSION; this is the author's final, peer-reviewed manuscript. The published version may be accessed by following the link in the citation at the bottom of the page.

${ }^{1}$ Upon completion of his engagement with the firm and data collection, the first author prepared and delivered an executive summary of his findings to the organization. Following sending the executive summary, he received a few emails from various client and consultant participants with responses such as "Results were interesting," "Project was great," and "Findings are interesting. And bold." Additionally, approximately one year after the study concluded, the first author emailed the completed dissertation to the client and consultant members who had expressed interest in reading it. Other than the comments mentioned above, no other feedback was provided regarding the results.

2 For the sake of accuracy, it is also worth noting that this figure does not include female participants involved in "corporate ILP" programs, where teams of individuals (e.g., senior leadership) participate in a version of the ILP.

3 One helpful resource recommended by CC proponents is The High-Purpose Company: The TRULY Responsible (2007) by Christina Arena, in which she spotlights 75 companies that are driven by their purpose (a key component of $\mathrm{CC}$ ). Given the relatively limited focus of our analysis (on development efforts), and considering that $\mathrm{CC}$ is in a nascent stage, projecting its longterm success is difficult.

However, based on our findings, we foresee continued problems with training leaders in the service of CC, without grappling with the problems of capitalism. Further, we thank one reviewer who commented "Are we to conclude that CC can never work short of some form of revolution?" We too wonder if it would take a revolution to achieve the aims of CC. At the most fundamental conceptual levels, CC and capitalism are incompatible, with capitalism working to undermine public good, appeals to promote more of a social welfare state, and think deeply about the investments in human beings in terms of education, quality child care, work-family considerations, particularly leaves and redefinitions of ideal workers, extreme jobs, and so on. The list of ironies when social change initiatives are meshed with capitalism are many-it may not take a political revolution, but it would take a revaluation of the worth of human beings and quality of life to derive complex solutions that transcend or reframe the ideological and pragmatic tensions and paradoxes we describe. We advocate continued research into the efforts that hope to create such discursive and material openings for social change.

[Citation: Journal/Monograph Title, Vol. XX, No. X (yyyy): pg. XX-XX. DOI. This article is @ [Publisher's Name] and permission has been granted for this version to appear in e-Publications@ Marquette. [Publisher] does not grant permission for this article to be further copied/distributed or hosted elsewhere without the express permission from [Publisher].] 